\title{
超清浄軸受鋼製造プロセスの開発
}

\author{
山口智則 ${ }^{* 1}$, 新貝 元 $^{* 1}$, 狩野 隆 $^{* 2}$, 岸 幹根 $^{* 1}$
}

\section{Development of a New Refining and Casting Process to Manufacture Ultra Clean Bearing Steel}

\author{
Tomonori Yamaguchi, Motoshi Shinkai, Takashi Kano, and Mikine Kishi
}

\section{Synopsis}

For the miniature races and balls in spindle motors of hard disc drives, there have been required the clean bearing steel with infinitesimal oxides, Ti inclusions and sulfides which originate acoustic noises. Chita Plant, Daido Steel, has established the new process, MRAC-SSS (Multi-function Refining and Advanced Casting - Special Solution and Soaking), to manufacture the ultra clean bearing steel. Its features are as follows.

(1) The tailored multi-functional refining process employing both LF and RH realizes the extremely low [O] and [Ti] levels in the molten steel.

(2) The tight sealing of the tundish prevents completely the secondary oxidation of the molten steel during continuous casting.

(3) The optimized reheating schedule for the cast bloom contributes to the siginificant reduction of Ti inclusions in number and size in the rolled wire or rod.

The ultra clean bearing steel manufactured through the new process proves to possess the remarkably prolonged contact rolling fatigue life.

\section{1.緒言}

近年, 高炭素高クロム軸受鋼は自動車の高出力化, 軽量 化のための長寿命要求に対する酸化物系介在物低減に加 え ハードディスクドライブスピンドルモータ用途のベア リング静肃性改善のためのチタン系炭窒化物，あるいはサ ルファイド系介在物低減のニーズが高まっている.大同特 殊鋼(株) (以下当社という) 知多工場ではこのニーズに応え るべく，溶鋼段階での低 [O][Ti][S] 化，凝固段階での介在 物の微細化技術により大気溶解において介在物を極限ま で低減した清浄鋼の製造技術を確立した．以下に关の概要 を報告する．

\section{2 ．超清净軸受鋼の製造プロセス概要}

\section{1 製造プロセス}

低 [O][Ti] 清浄軸受鋼の製造工程を Fig. 1 に示す . 製造
工程は電気炉出鋼後, LF 精錬, $\mathrm{RH}$ 式真空脱ガスを適用し た複合精錬，垂直型丸モールド連続鋳造機 No.2CCにより 溶製を行っている. 光の後熱間て鋳片を加熱炉へ搬送し， 適正な拡散焼なまし処理を施し分塊圧延によるビレット の製造, 製品サイズに応じた製品圧延を実施する. . との後 客先の要求に応じ, 球状化焼なまし, 酸洗, 被膜処理を実 施する工程となっている .

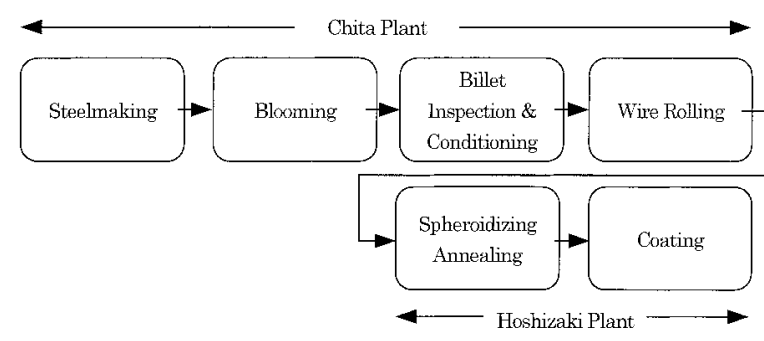

Fig.1. Manufacturing Process of the Ultra Clean bearing steel

* 1 大同特殊鋼(株)知多工場 (Chita Plant, Daido Steel Co., Ltd.), * 2 大同特殊鋼(侏)技術開発研究所 (Research \& Development Lab.,Daido Steel Co.,Ltd.) 


\section{2 清浄化のポイント}

超清浄軸受鋼の清浄化のポイントについて Fig.2 に示 す.酸化物系介在物については, LFにおける強脱酸精錬， $\mathrm{RH}$ における脱ガス精錬，介在物浮上分離の促進，No.2CC における再酸化の抑制により低 [O] 化,介在物の微細化を 実現している．Ti系介在物については，電気炉，LFでの 脱 [Ti] を促進し，添加合金，取鍋耐火物からの Ti 混入源 を徹底して排除することにより，低 [Ti] 化を実現した .こ の低 [Ti]，低 [O] を同時に実現するため,LF 処理の機能を 分割した精錬方法を実施していることがポイントである．

また介在物の分布調査を実施した結果，Ti 系介在物は 炭室化物として存在しており，粗大なものは鋳片での最終 凝固段階の偏析部に晶出していることが判明した．当社知 多工場はチタン炭室化物の改善のために上記低[Ti]化に加 え，低 $[\mathrm{N}]$ 化による TiN の晶出温度の低減，および偏析軽 減による晶出物の粗大化の抑制, 特殊熱処理による TiN の 再固溶促進を図るべく精錬・鋳造・加熱分塊プロセスを最 適化した。

当社では本プロセスを MRAC-SSS プロセス (Multifunction Refining \& Advanced Casting - Special Solution \& Soaking）と命名した . 以下に MRAC-SSS プロセス法につ いて概要を示す .

\subsection{1 酸化物系介在物の改善}

(1) 低 $[\mathrm{O}]$ 化

低 $[\mathrm{O}]$ 化処理として電気炉出鋼時に若干排出される酸化 スラグを $100 \%$ 除去し， $\mathrm{LF}$ て造滓材としての $\mathrm{CaO}, \mathrm{CaF}_{2}$ 他の投入と Al 添加による強脱酸精錬により LF 処理終了 後の溶鋼 $[O]$ レベルを極小化する . 兴の後 RH 式脱ガス装 置の徹底した真空度管理の下, 通常材より長時間処理を行
い, 精鍊末での低 $[\mathrm{O}]$ 化を実現した .

(2) 溶鋼再酸化の抑制

精錬段階で極限まで清浄化された溶鋼を大気との接触 により再酸化されない為に，連続鋳造における取鍋からタ ンディッシュへの溶鋼注入方法はロングノズル方式を採 用し，タンディッシュパウダーの使用，かつタンディッ シュ蓋の気密性を増し不活性ガスを導入する完全断気鋳 造を実施している.完全断気鋳造時の効果をFig.3 に示す が, タンディッシュ内雰囲気酸素を $0.1 \%$ 以下と改善して いる.(1),(2)により製品中 $[\mathrm{O}] \leqq 5 \mathrm{ppm}$ を実現した。

(3) 介在物浮上分離の促進

精錬工程においては，RH 真空下での還流時間確保によ る介在物の浮上分離の促進，連続鋳造工程においては, タ ンディッシュ堰の適性配置によるタンディッシュ内での 介在物浮上分離促進， $\mathrm{CC}$ 垂直マシン適用 ${ }^{1)}$ ，丸モールド による効率的電磁䚌拌 ${ }^{1)}$, 鋳造速度の適正化によりモール ド内での介在物浮上分離の促進を图っている．

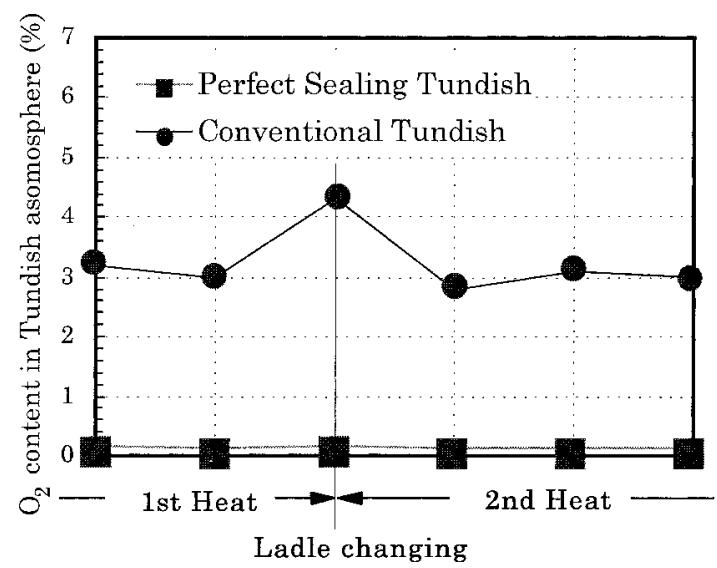

Fig.3. The effect of perfect sealing tundish.

\begin{tabular}{|c|c|c|c|c|c|c|}
\hline \multirow{2}{*}{\multicolumn{2}{|c|}{ Process }} & $\begin{array}{l}\text { Electric Are } \\
\text { Furnace }\end{array}$ & Ladle Furnace & $\begin{array}{l}\text { RH-type } \\
\text { degasoer }\end{array}$ & $\begin{array}{c}\text { No. } 2 \\
\text { Continuous } \\
\text { Casting } \\
\end{array}$ & $\begin{array}{c}\text { Bloom } \\
\text { Reheating } \\
\text { Furnace }\end{array}$ \\
\hline & & III & & & & \\
\hline \multirow{3}{*}{$\begin{array}{l}\text { Improvement } \\
\text { of Oxides } \\
\text { ( } \mathrm{Al}_{2} \mathrm{O}_{3} \text {-type) }\end{array}$} & $\begin{array}{c}\text { Decreasing } \\
\text { Oxygen }\end{array}$ & & - & - & & \\
\hline & $\begin{array}{l}\text { Promotion of } \\
\text { Inclusion } \\
\text { Removal } \\
\end{array}$ & & & - & & \\
\hline & $\begin{array}{l}\text { Prevention of } \\
\text { Secondary } \\
\text { Oxidation }\end{array}$ & & & & - & \\
\hline \multirow{3}{*}{$\begin{array}{c}\text { Improvement } \\
\text { of } T i(C, N)\end{array}$} & $\begin{array}{c}\text { Decreasing } \\
\text { Titanium }\end{array}$ & $\bullet$ & $\bullet$ & & & \\
\hline & $\begin{array}{l}\text { Decreasing } \\
\text { Nitrogen }\end{array}$ & & & $\bullet$ & & \\
\hline & $\begin{array}{l}\text { Minimizing } \\
\text { Ti inclusion }\end{array}$ & & & & - & $\bullet$ \\
\hline
\end{tabular}

Fig.2. The points of MRAC-SSS (Multi-function Refining and Advanced Casting - Special Solution and Soaking) process. 


\subsubsection{Ti系介在物の低減}

(1) 低 [Ti] 化

徹底した低 [Ti] 化を実現する為に,スクラップ配合段階 での低 [Ti] スクラップ厳選使用を実施し,電気炉における 酸化精錬でスクラップ中 $\mathrm{Ti}$ を $\mathrm{TiO}_{2}$ とし分離除去し,さら にLF 精錬においてもスラグ組成の適正化により脱 [Ti] を 行っている LFにおける脱 Tiの為の適正なスラグ組成は， Fig.4 に示す通り脱酸精錬スラグとは異なり低塩基度程有 利である.つまり LF 精錬工程においては，2.2.1 項で示し た通り強脱酸処理と脱 [Ti] 処理の二つの機能を分離し低 [Ti], 低 [O] を実現している .

また，Ti は合金，耐火物等あらゆる溶鋼接触物に含有し ている為, 乥れらの含有量を徹底して低減し，Ti のピッ クアップを抑制し鋼中 $[\mathrm{Ti}] \leqq 5 \mathrm{ppm}$ を実現した。

(2) 低 $[\mathrm{N}]$ 化

Ti 系介在物はチタン炭室化物として鋼塊中に存在して いるため,Ti系介在物の改善には低 $[\mathrm{N}]$ 化も重要なポイン トである.当社知多工場では脱 $[\mathrm{N}]$ 反応の阻害要因となる 表面活性元素である $[\mathrm{S}][\mathrm{O}]$ を LF 精鍊で撤底的に除去した 後, RH の還流時間を充分確保することにより脱 [N] 反応 を促進させ，鋼中 $[\mathrm{N}] \leqq 30 \mathrm{ppm}$ を安定して達成している．

(3)Ti 系介在物の微細化

先述したが, 粗大な Ti 系介在物は最終凝固部に相当す る中心部に存在することが判明している . Fig.5 は鋳片の 中心部から切出したサンプルをアルゴン雾囲気下で 1200 ${ }^{\circ} \mathrm{C}$ 加熱保持した後のTi系介在物の存在状態を示している． $\mathrm{Ti}$ 系介在物は，黑く変色した中心部に存在しており，変 色部分は $\mathrm{Cr}$ の濃化層であり，最終凝固部のミク口偏析部 に相当している．このことから粗大な $\mathrm{Ti}$ 系介在物を低減
させるためには, 偏析を軽減させることが重要であると考 えられ，これを当社知多工場 No.2CCでは鋳造速度を低減 させることにより実現した . 鋳片段階での Ti 系介在物個 数 , 大きさ分布をFig.6 に示すが, 鋳造速度の低減による $\mathrm{Ti}$ 系介在物の改善を示しており，特に中心部での改善効 果が大きいことが示された .

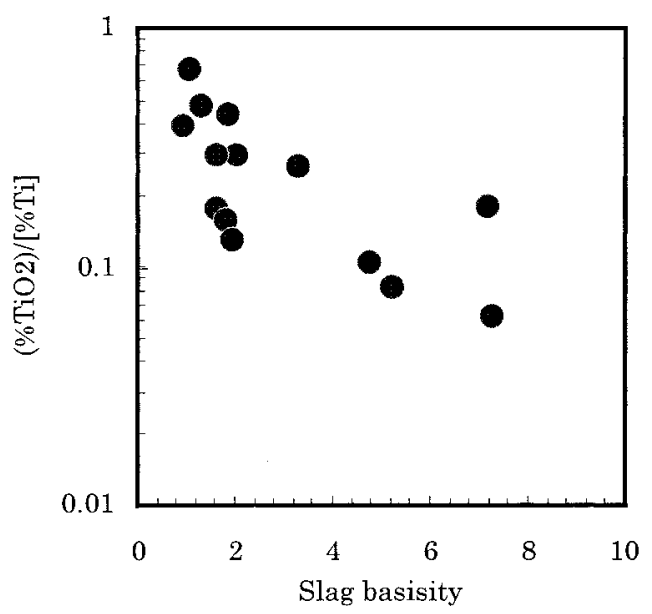

Fig.4. The effect of slag basicity on $\left(\% \mathrm{TiO}_{2}\right) /[\mathrm{Ti}]$ during Ladle Furnace process.

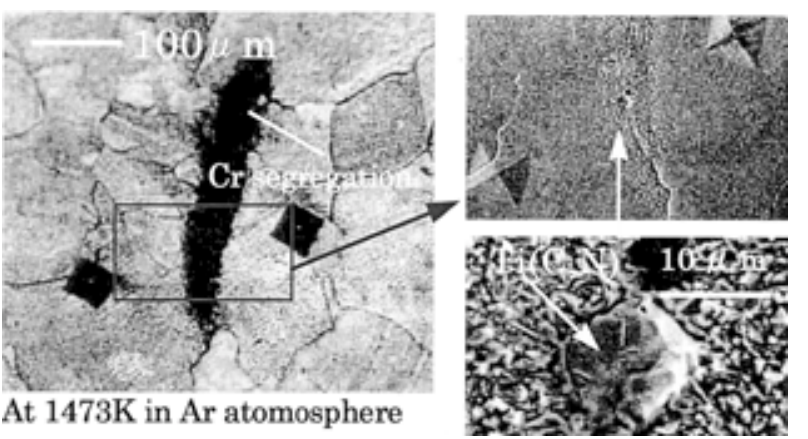

Fig.5. Micrographs of $\mathrm{Ti}(\mathrm{C}, \mathrm{N})$ in center position of casting bloom after heat treatment.

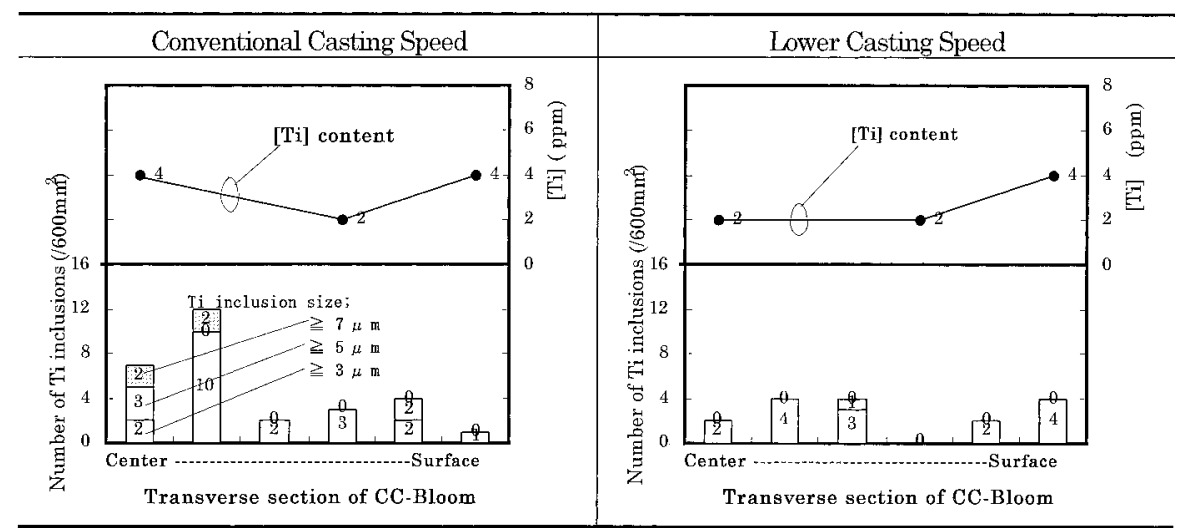

Fig.6. Distribution of Ti inclusions in the continuous casting bloom. 


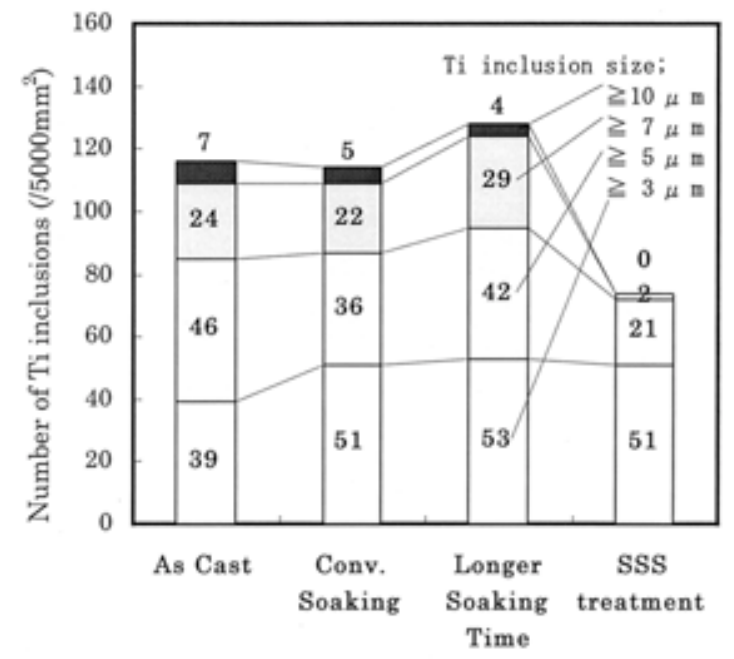

Fig.7. The effect of SSS (Special Solution and Soaking) treatment on the number and size of Ti inclusions.

また，鋳片段階で存在した Ti 系介在物をさらに微細に するために，分塊圧延前の加熱炉において鋳片の特殊熱処 理 (以下 SSS 処理) を実施している.これは Ti 系介在物 はチタン炭室化物であることより $\mathrm{Ti}(\mathrm{C}, \mathrm{N})$ の固溶温度以上 の温度で等温保持させ，マトリックスへ拡散させ Ti 系介 在物を微細化させることが狙いである，実験炉により通常 軸受鋼の拡散焼なまし処理条件，および SSS 処理による 鋳片の Ti 系介在物品位の影響を確認した . 供試材として $\mathrm{Ti}=5 \mathrm{ppm}, \mathrm{N}=30 \mathrm{ppm}$ の超清浄精錬を施した連続鋳造鋳片中 心部より $50 \mathrm{~mm} \times 50 \mathrm{~mm}$ の角サンプルを切出し, 弚れ光 れ鋳造まま，通常熱処理温度 + 通常処理時間，通常熱処理 温度 + 処理時間延長, SSS 処理の条件で Ti 系介在物品位 を調査した . 光の結果をFig.7 に示す．通常熱処理温度に おいては処理時間を延長しても Ti 系介在物は鋳造ままと 比較し改善効果はほとんどないが, SSS 処理により Ti 系 介在物は大きさ，個数共に低減することが証明された．

\section{3. 超清浄軸受鋼の清浄度, およ び転動寿命評価}

\section{1 酸化物系介在物評価}

\section{(1) 鋼中 $[\mathrm{O}]$ 值評価}

酸素分析方法は表面污染酸素を除去した微量酸素分析 法 ${ }^{2)}$ を採用し，低 $[\mathrm{O}]$ 域を精度良く分析できる体制とし た。微量酸素分析法による結果と従来の分析方法により [O] 值の差違を Fig.8 に示すが, 従来分析方法の結果は低 $[\mathrm{O}]$ 域でばらついており，微量酸素分析方法により，低 $[\mathrm{O}]$ 域の $[\mathrm{O}]$ 值を精度良く把握できることが示されている.こ
のように微量酸素分析法は MRAC プロセスにより溶製さ れた超清净軸受鋼を評価する上で極めて重要であり，本分 析法により MRAC プロセスにより溶製された鋼中 [O]5ppm 以下を精度よく評価することが可能となった ．

(2) 個数カウント評価

通常溶製の軸受鋼と MRAC プロセスで溶製した超清净 軸受鋼を直径 $5.5 \mathrm{~mm}$ まで線材圧延を実施し清净度の評価 を行った. D/2 断面で縦断ミクロホルダーを作成し, 光学 顕微鏡による介在物の個数カウント評価を実施した結果 をFig.9,10 に示す. 介在物は, クラスター状に連なって 存在する $\mathrm{Al}_{2} \mathrm{O}_{3}$ 系主体の介在物と $\mathrm{CaO}-\mathrm{Al}_{2} \mathrm{O}_{3}$ 系介在物のよ うに伸長した状態で存在する介在物の 2 種類に区分し評 価した. $\mathrm{Al}_{2} \mathrm{O}_{3}$ 系介在物は個数，大きさ共に大幅に改善さ

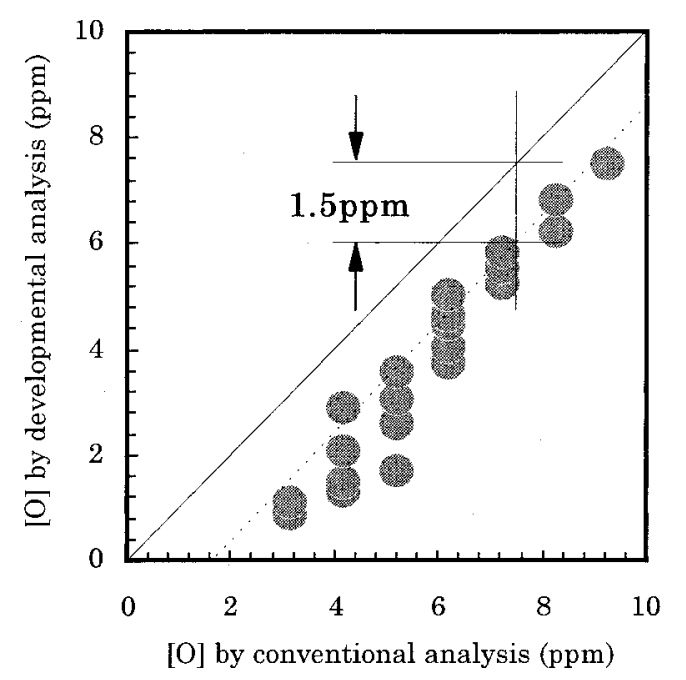

Fig.8. Relationship between [O] by conventional analysis and [O] by developmental analysis.

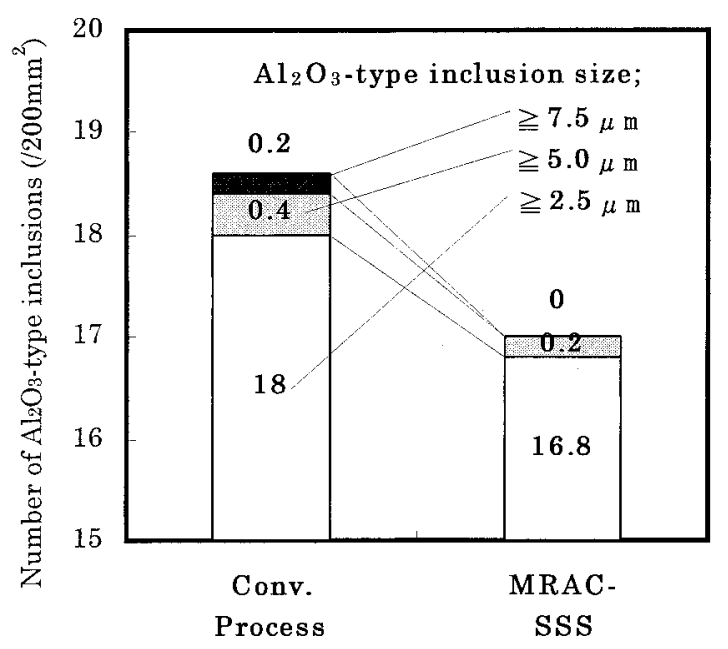

Fig.9. Number and size of $\mathrm{Al}_{2} \mathrm{O}_{3}$ type inclusions. 


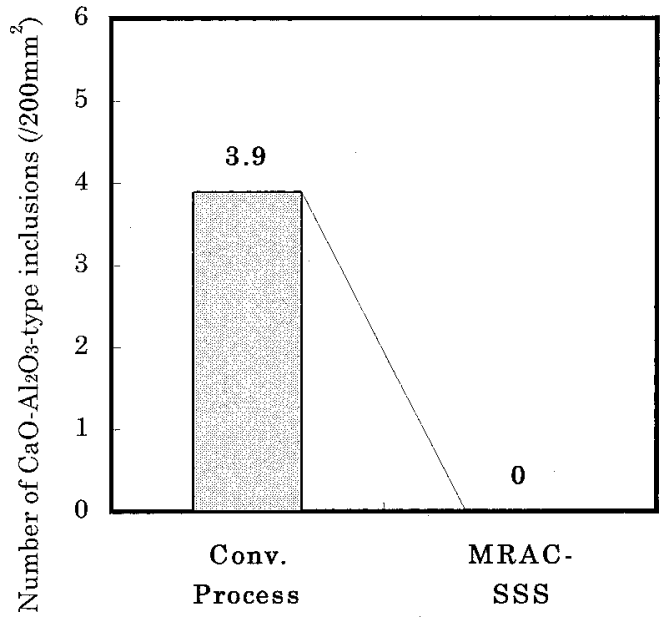

Fig.10. Number and size of $\mathrm{CaO}-\mathrm{Al}_{2} \mathrm{O}_{3}$ type inclusions.

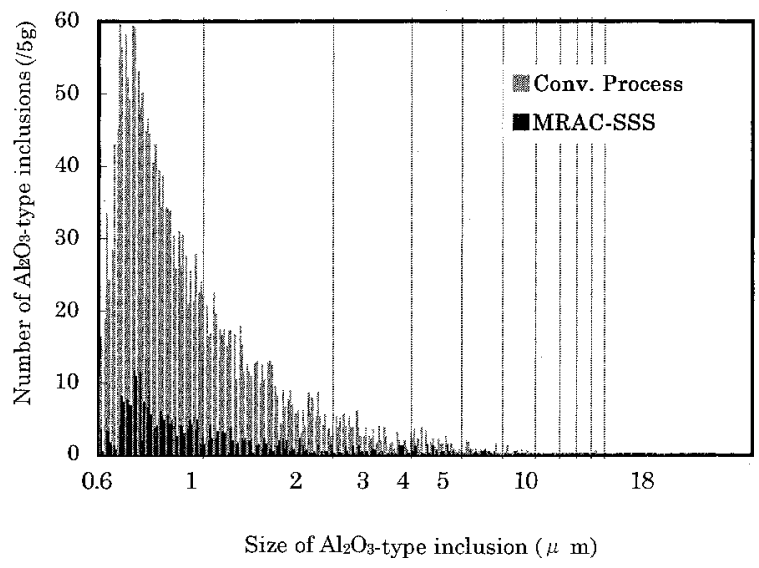

Fig.11. Number and size of $\mathrm{Al}_{2} \mathrm{O}_{3}$ type inclusions by particle counter.

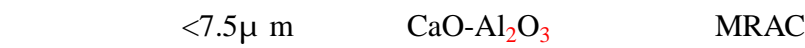
プロセスにより皆無となった .

(3) 酸溶解抽出 - 細孔電気抵抗法評価

(2)項同樣の溶製条件を施した軸受鋼の鋼片 (155mm.sq.) から切出した小片サンプルを硫酸, および過マンガン酸カ リウムにより酸溶解し $\mathrm{Al}_{2} \mathrm{O}_{3}$ 系, および $\mathrm{MgO}-\mathrm{Al}_{2} \mathrm{O}_{3}$ 系介 在物を抽出した .この介在物について細孔電気抵抗法によ る介在物体積測定を実施し，大きさ，個数分布を評価し た．測定装置は,ベックマンコールター株式会社製マルチ サイザーIIIを使用し ,介在物は $0.6 〜 18 \mu \mathrm{m}$ の範囲の径の ものを測定した . 結果を Fig.11に示すが，MRAC-SSS 処 理による超清浄軸受鋼は通常軸受鋼に比べて,クラスター を形成すると考えられる $3 \mu \mathrm{m}$ 以下の $\mathrm{Al}_{2} \mathrm{O}_{3}$ 介在物個数が 大幅に低減している

\section{$3.2 \mathrm{Ti}$ 系介在物評価}

(1) 個数カウント評価
$\mathrm{Ti}$ 系介在物についても酸化物系介在物同樣に通常溶製の 軸受鋼と MRAC-SSS プロセスで溶製した超清浄軸受鋼を 線材圧延 ( $\varphi 5.5 \mathrm{~mm})$ し D/2 断面で縦断ミクロホルダーを 作成し, 光学顕微鏡による介在物個数カウント評価を実施 した . 結果をFig.12に示すが, 横軸に [Ti][N] の溶解度積 から算出した $\mathrm{TiN}$ 平衡析出温度（式1）をとり，縦軸に介 在物個数を評価した .

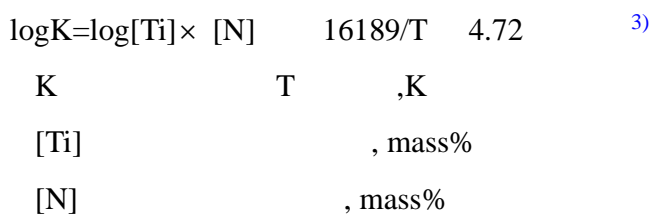
すると $\mathrm{Ti}$ 系介在物個数は低減傾向にある.さらに SSS 処 理により同一 [Ti][N] 含有量における個数の低減効果があ ることが示された . また Fig.13 に溶製条件別の Ti 個数カ

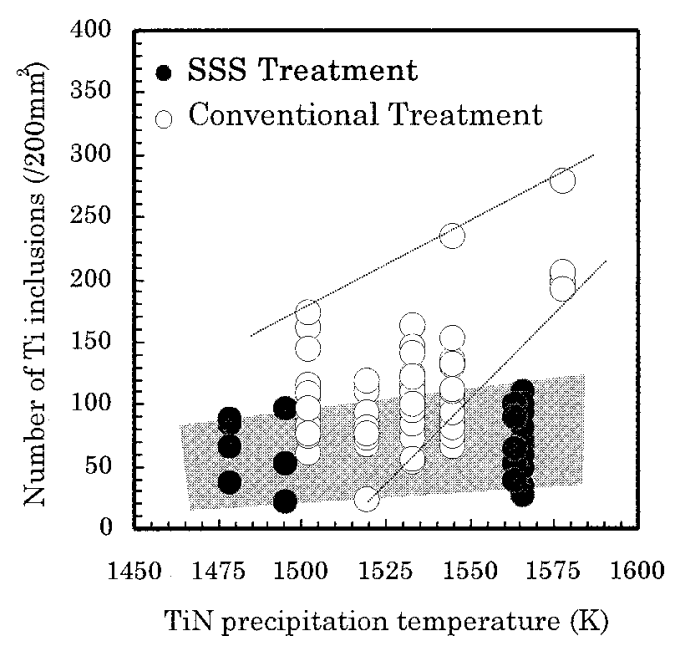

Fig.12. Relationship between TiN precipitation temperature and number of $\mathrm{Ti}$ inclusions.

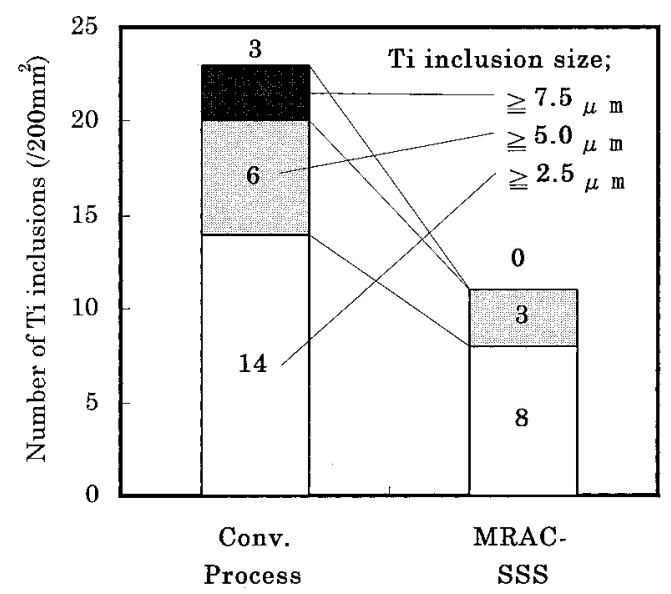

Fig.13. Number and size of Ti inclusions. 
ウント評価を示したが,Fig.12 で示された個数低減と同時 に $7 \mu \mathrm{m}$ 以上の粗大な $\mathrm{Ti}$ 系介在物か皆無となっており， SSS 処理により凝固偏析部に晶出した粗大な Ti 系介在物 が母相中へ再固溶していることが推定される .

\section{3 転動寿命評価}

MRAC-SSS プロセスにより製造した超清浄軸受鋼と従 来プロセスの清浄鋼の転動寿命評価を行った .また参考と して MRAC プロセスにて溶製した鋳片を母材とした 2 次 溶解材もあわせて評価した .

(1) 供試材

Table 1 に供試材の成分を示す .ここで示された [O] 值 は,表面污染影響を除去した微量酸素分析法により分析さ れた值である . A 鋼は MRAC-SSS プロセスで容製された 超清浄鋼である. $\mathrm{B} \sim \mathrm{D}$ 鋼は従来の清浄鋼, $\mathrm{E}$ 鋼は MRAC プロセスで溶製された鋳片を母材とし当社渋川工場で特 殊溶解真空 ESR-VAR 処理を施した究極の清净鋼である。 供試材は各条件で溶製された鋼片を $\varphi 65$ まて鍛伸し，球 状化焼なまし一焼入れ焼戻し処理を施した後，機械加工に より $\varphi 62$ の供試材を作製した .

(2) 試験条件

スラスト型転動寿命疲労試験条件を Table 2 に示す．

(3) 寿命結果

Fig.14に $\mathrm{L}_{10}$ 寿命を評価した結果を示すが,微量酸素分 析法による $[\mathrm{O}]$ 值でよく整理され，従来清浄鋼と比較し， MRAC-SSS プロセスにより，約 $25 \% \mathrm{~L}_{10}$ 寿命が向上するこ とか確認された .また本結果により転動寿命に影響する因 子として $[\mathrm{O}]$ 值の影響が大きく $[\mathrm{Ti}]$ 值の影響は小さいこと が推察される。

Table 1. Chemical compositions of high- $\mathrm{C}$ bearing steel for rolling fatigue test.

\begin{tabular}{c|c|c|c|c|c|c}
\hline Mark & $\mathrm{C}$ & $\mathrm{S}$ & $\mathrm{Cr}$ & $\mathrm{O}$ & $\mathrm{N}$ & $\mathrm{Ti}$ \\
\hline \hline $\mathrm{A}$ & 0.99 & 0.001 & 1.48 & 3.4 & 30 & 3 \\
\hline $\mathrm{B}$ & 1.01 & 0.003 & 1.46 & 6.1 & 35 & 5 \\
\hline $\mathrm{C}$ & 1.00 & 0.003 & 1.45 & 5.7 & 60 & 19 \\
\hline $\mathrm{D}$ & 1.00 & 0.007 & 1.48 & 6.5 & 60 & 14 \\
\hline $\mathrm{E}$ & 1.01 & 0.001 & 1.42 & 1.6 & 25 & 6 \\
\hline \multicolumn{6}{c}{ mass\%([O],[Ti],[N] in ppm) }
\end{tabular}

Table 2. Experimental conditions of rolling fatigue test (thrust disk specimen).

\begin{tabular}{lc|c}
\hline Specimen diameter & $\mathrm{mm}$ & 62 \\
\hline Max. Stress & $\mathrm{GPa}$ & 4.9 \\
\hline Speed & $\mathrm{rpm}$ & 1800 \\
\hline Lubricant & & Turbine Oil \#68 \\
\hline
\end{tabular}

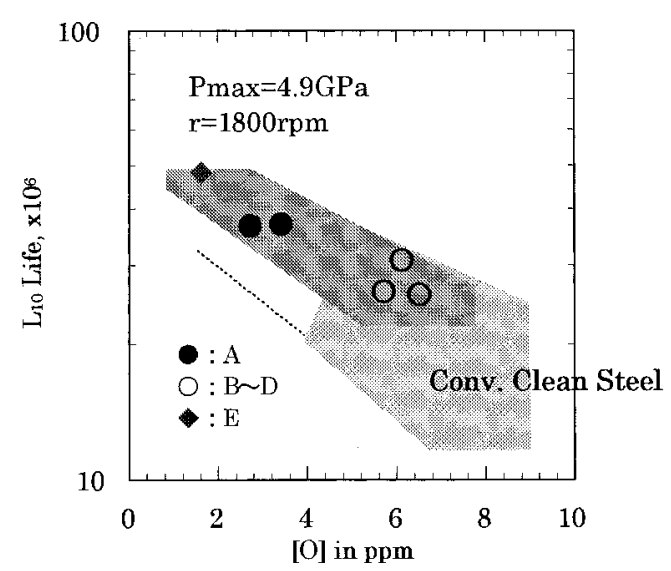

Fig.14. The effect of $L_{10}$ life on $[O]$ by development analysis.

\section{4 . 結 言}

当社知多工場で開発された超清浄軸受鋼溶製方法であ る MRAC-SSS プロセスにより, 以下に示す改善効果が得 られた。

(1)LF-RH の複合精錬，連続鋳造，分塊圧延前加熱処理を 最適化したことにより低 $[\mathrm{O}]$, 低 $[\mathrm{Ti}]$ を実現し, さらに酸 化物系, $\mathrm{Ti}$ 系介在物の個数を半減し, $7.5 \mu \mathrm{m}$ 以上の介在 物を皆無とした。

（2）転動寿命が通常清净鋼対比，約 $25 \%$ 向上した .

今後は本プロセスの効果として期待できる音響特性の 評価, および客先清净度要求のある他鋼種, 他用途へ適用 拡大を図っていく所存である.

\section{(文 献)}

1)森井, 早川稲垣, 高橋 横山 鈴木: 電気製鋼, 64(1993), 13.

2)伊藤，小池:CAMP-ISIJ, 13(2000), 510.

3)沢村 盛 鉄と鋼, 43(1963)，31. 